Journal de la Société des américanistes

Journal de la Société

des américanistes

tome $93, n^{\circ} 2$

\title{
Henry B. Nicholson (1925-2007)
}

\section{Guilhem Olivier}

\section{CpenEdition}

Journals

Édition électronique

URL : https://journals.openedition.org/jsa/8233

DOI : 10.4000/jsa.8233

ISSN : $1957-7842$

Éditeur

Société des américanistes

Édition imprimée

Date de publication : 2 décembre 2007

Pagination : 153-171

ISSN : 0037-9174

\section{Référence électronique}

Guilhem Olivier, «Henry B. Nicholson (1925-2007) », Journal de la Société des américanistes [En ligne],

93-2 | 2007, mis en ligne le 08 février 2008, consulté le 03 septembre 2022. URL : http://

journals.openedition.org/jsa/8233; DOI : https://doi.org/10.4000/jsa.8233 


\section{NÉCROLOGIE}

Henry B. NichOLSON (1925-2007)

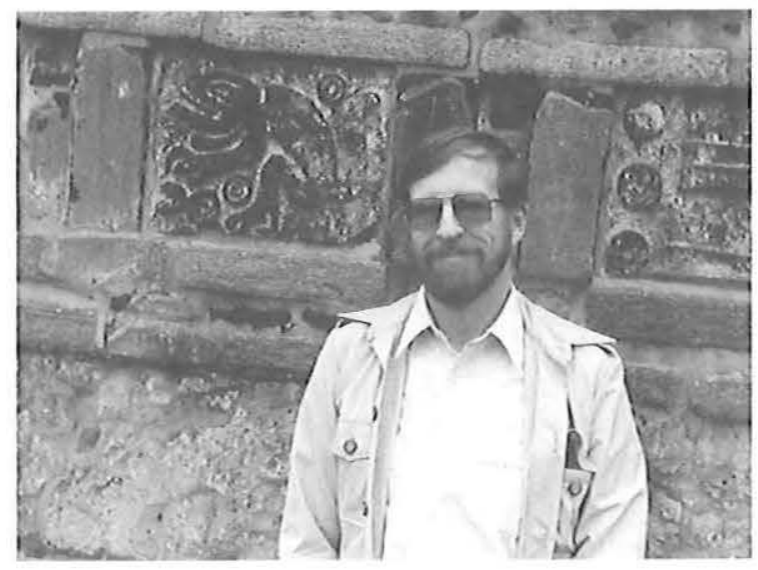

Le 2 mars 2007, Henry B. Nicholson ${ }^{1}$ s'est endormi chez lui, au milieu de ses livres, pour ne plus jamais se réveiller. Professeur émérite d'anthropologie à l'université de Californie (UCLA), il avait dédié sa vie à l'étude de l'ancien Mexique, en particulier à l'art et à la religion aztèques dont il était devenu l'un des plus grands spécialistes, mondialement reconnu.

Après des études d'anthropologie à l'université de Californie, Nicholson participa à la Seconde Guerre mondiale en Allemagne, puis aux Philippines (1944-1945). Suivirent de nouvelles études d'anthropologie à Berkeley, puis à l'université d'Harvard où il allait côtoyer de grandes figures de l'américanisme de l'époque comme Michael Coe, John Glass, Tatiana Proskouriakoff, William Sanders, John E. Thompson et Gordon Willey ${ }^{2}$. Son activité professionnelle débuta en 1956 à l'université de Californie où il enseigna jusqu'en 1991, obtenant le titre de " Professor Emeritus of Anthropology ».

Passionné d'art et d'archéologie - il dirigea et participa à des fouilles à Cerro Portezuelo, Chimalhuacan et Ixtapaluca Viejo ${ }^{3}-$, Henry B. Nicholson a réuni tout au long de sa vie une inestimable documentation concernant les peintures, statues, bas-reliefs, objets en céramique, etc. de l'ancien Mexique central. Infatigable visiteur de sites archéologiques, de musées et de collections privées au 
Mexique, aux États-Unis et en Europe, Nicholson a rassemblé d'innombrables photographies et fiches bibliographiques dans son célèbre "Aztec Archive » déposé à l'université de Californie (UCLA) (Olmedo Vera 1998 ; Quiñones Keber 2007). De nombreuses publications ont été consacrées à ces matériaux : l'un des premiers articles de Nicholson concerna un bas-relief fragmentaire qu'il reconstitua et interpréta comme étant la naissance de Tezcatlipoca à partir de la divinité de la terre Tlaltecuhtli (1954). Plus tard, dans un hommage à Hermann Beyer, Nicholson aborda le thème complexe de «The Chapultepec Cliff sculpture of Motecuhzoma Xocoyotzin » (1961c). Il s'agit, à mon avis, d'un des écrits les plus brillants du spécialiste nord-américain, un véritable modèle méthodologique dans lequel, à partir de quelques fragments mutilés de bas-reliefs, il parvient à reconstituer un grand ensemble iconographique à l'aide des sources ethnohistoriques. Outre une longue liste d'études minutieuses consacrées à d'autres statues ou monuments spécifiques ${ }^{4}$, nous devons à Nicholson une analyse de la polychromie de la sculpture du Mexique central (1985c), l'édition d'un catalogue érudit de sculptures aztèques (1983c, en collaboration avec Eloise Quiñones Keber) et surtout une brillante synthèse dédiée à la sculpture aztèque publiée dans le célèbre Handbook of Middle American Indians (1971c).

Les questions de style devaient également susciter l'intérêt d'Henry B. Nicholson. Dans plusieurs publications, il propose que le terme "Mixteca-Puebla » corresponde en fait à un "style " partagé par plusieurs peuples des régions de Oaxaca, Puebla-Tlaxcala et de la Côte du Golfe, et non pas à une culture ou civilisation comme l'a affirmé jadis George Vaillant. Sur ce thème, outre des articles devenus des classiques $(1960,1961,1966,1982 c)$, Nicholson a coordonné, en collaboration avec Eloise Quiñones Keber, la publication d'un important volume collectif (1994).

Parallèlement à ces recherches, Henry B. Nicholson a effectué des travaux sur les manuscrits pictographiques des anciens Mexicains : élaboration d'une liste des codex (1968b) en vue de la publication d'un bilan de recherche (1962) et d'un important article sur les sources ethnohistoriques (1975); études sur l'origine géographique des membres du « groupe Borgia » (1966b) et du Codex Borbonicus (1974c, 1988e), ainsi que sur l'histoire du Codex Mendoza (1992). On ajoutera que Nicholson a consacré à diverses éditions de codex des comptes rendus extrêmement minutieux qui sont souvent cités, à l'instar d'articles scientifiques, dans les bibliographies spécialisées, fait rare digne d'être signalé ${ }^{5}$.

Tout au long de sa carrière, Henry B. Nicholson a été fasciné par la figure protéiforme de Topiltzin Quetzalcoatl. À l'origine de cette passion, comme il l'explique dans un texte publié dans un volume d'hommage qui lui était dédié (Cordy-Collins et Sharon 1993, p. 113), le jeune Nicholson assista en 1936 à une conférence au cours de laquelle un professeur débutant identifiait Quetzalcoatl à Jésus-Christ. Plus tard, il devait consacrer sa thèse de doctorat, soutenue à l'université d'Harvard, précisément à Topiltzin Quetzalcoatl : a problem in Meso- 
american ethnohistory (1957). Il s'agissait pour Nicholson de réunir et d'analyser toutes les sources disponibles concernant le personnage " historique » de Topiltzin Quetzalcoatl. À l'issue d'un long parcours au travers d'une ample documentation qu'il organise de façon claire, l'auteur conclut, non sans réserves, à la probable existence d'un personnage appelé Topiltzin Quetzalcoatl qui aurait marqué les débuts de l'histoire toltèque. Il ajoute que cette figure historique - souvent confondue avec la divinité Ehecatl Quetzalcoatl - aurait servi de modèle à de nombreux dirigeants postérieurs qui adoptèrent son nom. Enfin, Nicholson examine l'influence du mythe du retour annoncé de Quetzalcoatl sur le déroulement de la conquête du Mexique, un thème auquel il a consacré plus tard un excellent petit ouvrage (2001). De fait, Nicholson devait revenir à plusieurs reprises au cours de sa carrière sur des questions soulevées dans sa thèse, comme les rapports entre l'« homme » Topiltzin et le « dieu » Quetzalcoatl (1979), la divinité mixtèque appelée « 9 Vent » (1978b), une critique de l'identification de « 4 jaguar » à Topiltzin Quetzalcoatl (2005d) ou encore l'iconographie du « Serpent à plumes » (1987d, 2000). Précisons que la thèse de doctorat de Nicholson - longtemps fort difficile à consulter $-{ }^{6}$ ne fut publiée qu'en 2001 par l'University of Colorado Press, l'auteur ayant pris soin d'ajouter une nouvelle introduction, extrêmement érudite, où il compile et commente les nouveaux matériaux bibliographiques publiés au cours des cinquante dernières années.

L'intérêt d'Henry B. Nicholson pour les anciennes sources écrites s'est aussi traduit par plusieurs études dédiées à l'œuvre de Bernardino de Sahagún et de ses informateurs indigènes. Outre des articles généraux consacrés à la vie et à l'œuvre du franciscain (2001h, 2002b), on retiendra ses travaux sur le séjour de Sahagún à Tepepulco (1973c, 1974b) ainsi que la compilation critique de l'immense production scientifique suscitée par les écrits du franciscain (1988b, 1988c). De même, Nicholson a publié plusieurs études sur la partie iconographique, particulièrement riche, des Primeros memoriales : représentations de divinités comme Huitzilopochtli et Chalchiuhtlicue (1988d), iconographie des fêtes des vingtaines (2002c), ou encore le fameux et polémique plan de l'enceinte sacrée du Grand Temple illustré dans ce même manuscrit (2003). Enfin, on lui doit la réalisation finale d'un grand projet entrepris par Thelma Sullivan dont le décès en 1991 avait suspendu l'exécution. Il s'agit de la publication d'un superbe facsimilé des Primeros memoriales (Sahagún 1993) et de la traduction complète du texte nahuatl inclus dans ce manuscrit, demeuré en partie inédit (1997). Entouré de spécialistes comme Eloise Quiñones Keber et Wayne Ruwet et de traducteurs de la qualité de Charles E. Dibble et Arthur J. O. Anderson - qui complétèrent les traductions de Thelma Sullivan -, Nicholson s'est chargé de l'introduction, de la bibliographie et surtout des nombreuses notes érudites de l'ensemble du livre.

Le panthéon complexe des anciens Mexicains a constitué un autre grand thème de recherche pour Henry B. Nicholson. Dès 1959, il publie une première contribution intitulée " Los principales dioses mesoamericanos » dans le volume 
Esplendor del México antiguo. Plus tard, Nicholson devait réaliser une remarquable synthèse, « Religion in Pre-Hispanic Central Mexico » (1971d), sans doute le plus célèbre et cité de ses écrits. Outre l'exposition des sources, des mythes, de la vision du monde et des rituels, l'auteur propose de regrouper les innombrables divinités préhispaniques en trois grand groupes - I. Celestial Creativity-Divine Paternalism ; II. Rain-Moisture-Agricultural Fertility; III. War-SacrificeSanguinary Nourishment of the Sun and Earth -, chacun comprenant une série de complex associés aux principales divinités : Ometeotl Complex, Tezcatlipoca Complex, Xiuhtecuhtli Complex, Tlaloc Complex, etc. Nicholson décrit succinctement ces « complexes divins » en soulignant les rapports qui les relient ou les opposent. On trouvera également dans cette contribution des tableaux utiles où apparaissent les différents noms des dieux et des fêtes religieuses. Nicholson devait poursuivre, dans des travaux postérieurs, sa quête des divinités précolombiennes comme Xipe Totec (1989b) et le groupe des divinités du vin d'agave (1991).

Quel que soit le thème abordé, Henry B. Nicholson faisait preuve d'une extraordinaire érudition au bénéfice de laquelle il maniait aisément l'anglais, l'espagnol, le français et l'allemand. Si la mode, hélas, n'est plus guère à citer les travaux anciens, on méditera cependant sur cette phrase de Nicholson (1973d, pp. 362-363), alors qu'il présentait dans une synthèse magistrale l'œuvre immense du grand mexicaniste Eduard Seler : "Without sufficient knowledge of the stepby-step development of any field of research one's perspective cannot be very sophisticated, entirely apart from the ever-present danger of needlessly repeating work done long before ». Parallèlement à sa profonde connaissance des sources et de la littérature spécialisée, on est frappé par la diversité des thèmes abordés par Nicholson, toujours avec une rigueur scientifique exemplaire. Personnalité attachante, conteur hors pair, il ne manquait jamais de répondre à une lettre et partageait généreusement son immense savoir. C'est dire l'extraordinaire reconnaissance et la profonde tristesse que la communauté scientifique ressent face à sa soudaine disparition.

\section{NOTES}

1. Je tiens à remercier Éloïse Quiñones Keber pour son aide dans la préparation de ces pages.

2. On trouvera plus de détails sur sa carrière dans un texte autobiographique de Nicholson, publié dans un libre d'hommage qui lui était dédié (Cordy-Collins et Sharon 1993, pp. 111-118) et dans l'obituaire précis et chaleureux rédigé par Eloise Quiñones Keber (2007).

3. Au sujet de ces fouilles voir Nicholson (1961d, 1963h, 1964e, 1966e, 1972, 2001c, 2005).

4. Parmi lesquelles on peut citer ses recherches sur le temalacatl de Tehuacan (1956), un autel quadrangulaire dédié à Tezcatlipoca (1958), plusieurs statues de divinités féminines de la fertilité (1961b, 1963b, 1964), un bas-relief de Tlaltecultli - publié dans le Journal de la Société des Américanistes - (1967c), deux statues en bois découvertes près de Tezcoco (1968), le célèbre monument de " Coyolxauhqui-Chantico » du Templo Mayor (1985), l'iconographie d'un teponaztli (1988h), plu- 
sieurs monuments dédiés au soleil dont le " Calendrier aztèque » $(1993,1995,2000 \mathrm{c})$, la statue en pierre d'un aigle (2004) et l'iconographie liée à la mort représentée sur des monuments en pierre (2006).

5. Voir ses comptes rendus des éditions du Codex Borgia (1966i), Codex Selden 3135 (1967f), Codex Colombino (1968c) et Codex Cospi (1972d).

6. À ma connaissance, aucun exemplaire de cette thèse n'était disponible à Paris, tandis qu'à Mexico on pouvait seulement consulter une photocopie à la Biblioteca nacional.

\section{RÉFÉRENCES BIBLIOGRAPHIQUES}

Cordy-Collins Alana et Douglas Sharon (éd.)

1993 Current topics in Aztec studies : essays in honor of Dr: H. B. Nicholson, San Diego Museum Papers, 30, San Diego, California.

Noguez Xavier

2007 «Una breve semblanza del doctor Henry B. Nicholson (1925-2007) », Arqueología Mexicana, XV (86), pp. 12-14.

Olmedo Vera Bertina

1998 «Henry B. Nicholson. Presencia en la arqueología y la etnohistoria de Mesoamérica ", Arqueología Mexicana, VI (31), pp. 60-65.

QUIÑONES KEBER Éloïse

2007 "In Memoriam. Gifts of the feathered serpent. The life and career of H. B. Nicholson (1925-2007) ", Ancient Mesoamerica, 18, pp. 1-8.

SAHAGÚN Fray Bernardino de

1993 Primeros Memoriales, facsimile edition, University of Oklahoma Press, Norman, Oklahoma [en coopération avec Real Academia de la Historia, Madrid].

Guilhem OLIvier

Instituto de investigaciones históricas/UNAM, Mexico

\section{BibliographiE DE HENRY B. NiCHOLSON}

1953 «On a supposed Mesoamerican "Thin Orange" vessel from Ecuador », American Antiquity, 19 (2), pp. 164-166, Salt Lake City.

1954 "The birth of the smoking mirror ", Archaeology, 7 (3), pp. 164-170, Cambridge, Massachussetts.

1954b "The archaeology of northern Manabí and Esmeraldas Provinces, Ecuador, and the Southern Nariño Province, Colombia " [duplicated].

1955 «Native historical traditions of nuclear America and the problem of their archaeological correlation ", American Anthropologist, 57 (3), pp. 594-613, Menasha.

1955b «Montezuma's zoo », Pacific Discovery, 8 (4), pp. 3-11, San Francisco.

1955c «The archaic tradition in Puerto Rico " [avec Ricardo Alegría et Gordon R. Willey], American Antiquity, 21 (2), pp. 113-121, Salt Lake City.

$1955 \mathrm{~d}$ "Tawantinsuyu : ethnohistory and archaeology » [duplicated].

1956 "The Temalacatl of Tehuacan », El México Antiguo, 8, pp. 95-134, Mexico. 
1956b « Report on a Mesa Redonda sponsored by the Sociedad Mexicana de antropología : calendric systems of pre-hispanic Central Mexico (December 5-12, 1955) ", Bulletin of the American Anthropological Association, 4 (1), p. 18.

1956c «Aztec style calendric inscriptions of possible historical significance : a survey » [mimeographed].

1956d «Review : Alfonso Villa Rojas, Los mazatecos y el problema de la Cuenca del Papaloapan ", American Anthropologist, 58 (2), pp. 379-381, Menasha.

1956e "Review : José Díaz-Bolio, La Serpiente emplumada : eje de culturas », American Antiquity, 21 (4), pp. 435-436, Salt Lake City.

1957 «Topiltzin Quetzalcoatl of Tollan : a problem in Mesoamerican ethnohistory », $\mathrm{Ph}$. D. dissertation, Harvard University.

1957b « Report on the archaeological sessions of the Fifty-Fifth annual meeting of the American anthropological association : Santa Monica, December 28-30, 1956 ", Archaeology, 10 (1), pp. 64-65, Cambridge, Massachussetts.

1957c «Review : John Sorenson, A chronological ordering of the Mesoamerican PreClassic, and Arden King, Archaeological remains from the Cintalpa region, Chiapas, Mexico ", American Anthropologist, 23 (2), part 1, pp. 375-376, Menasha.

1957d "Review : John Paddock et al., Excavations at Yagul : I », American Antiquity, 23 (2), part 1, pp. 195-196, Salt Lake City.

1958 "An Aztec monument dedicated to Tezcatlipoca ", Miscellanea Paul Rivet: Octogenaria Dicata, Universidad Nacional Autónoma de México/Instituto de Historia, Publicaciones, primera serie $n^{\circ}$ 50, tomo I, México, pp. 592-607.

1958 b "The settlement pattern approach in contemporary American archaeology ", American Antrhopologist, 60 (6), part 1, pp. 1189-1192, Menasha.

1958c "Review : Miguel Covarrubias, Indian art of Mexico and Central America", American Anthropologist, 60 (4), pp. 784-785, Menasha.

1959 «Los principales Dioses Mesoamericanos », Esplendor del México Antiguo, 1, Centro de Investigaciones Antropológicas de México, Mexico, pp. 161-178 [ $2^{\mathrm{e}}$ édition : Editorial del Valle, Mexico, 1976].

1959b "Review : Víctor W. Von Hagen, The Aztec: man and tribe », American Antiquity, 25 (1), pp. 156-159, Salt Lake City.

1959c "Some recent publications: Middle America », American Antiquity, 25 (1), pp. 156-159, Salt Lake City.

1959d «Notes and news: Middle America » [avec Tatiana Proskouriakoft], American Antiquity, 24(3), pp. 345-347;25(1), pp. 150-151;25(2), pp. 305-309, Salt LakeCity.

1960 "The Mixteca-Puebla concept in Mesoamerican archaeology: a re-examination ", Men and cultures : selected papers from the Fifth International Congress of anthropological and ethnological sciences, Philadelphia, September 19, 1956, pp. 612-617, Philadelphia.

$1960 \mathrm{~b}$ "Ethnohistory: Mesoamerica » (introduction and annotated bibliography), Handbook of Latin American Studies, 22, pp. 30-42, Gainesville.

1960c «Review : Frederick Peterson, Ancient Mexico », American Journal of Archaeo$\log y, 64$ (1), pp. 120-122, Boston.

1960d «Review: Arthur J. O. Anderson and Charles E. Dibble, Florentine Codex: General history of the things of New Spain. Book 11-The Merchants. Fray Bernardino de Sahagún », American Antiquity, 25 (3), pp. 436-437, Salt Lake City. 
1960e "Notes and news : Middle America ", American Antiquity, 25 (4), pp. 635-637; 26 (1), pp. 142-146, Salt Lake City.

1961 "The use of the term "Mixtec" in Mesoamerican archacology ", American Antiquity, 26 (3), part 1, pp. 431-433, Salt Lake City.

$1961 \mathrm{~b}$ "An oustanding Aztec sculpture of the water goddess », Masterkey, 35 (2), pp. 44-45, Los Angeles.

1961c "The Chapultepec Cliff sculpture of Motecuhzoma Xocoyotzin », El México Antiguo, 9, pp. 379-444, Mexico.

1961d «A brief progress report on the excavations at Cerro Portezuelo, Valley of Mexico » [avec Frederic Hicks], American Antiquity, 27 (1), pp. 106-108, Salt Lake City.

1961e «Ethnohistory: Mesoamerica» (introduction and annotated bibliography), Handbook of Latin American Studies, 23, pp. 57-70, Gainesville.

1961 «Review : Wilhelm Bierhenke et al. (eds), Amerikanische Miszellen : Festband Franz Termer in Freunschaft und Vorehrung gewidment von Freunden, Kollegen und Schulern zur Volledung der 65. Lebensjahre », American Anthropologist, 63 (5), part 1, pp. 1109-1112, Menasha.

1961 «Notes and news : Middle America », American Antiquity, 26 (4), pp. 594-600, Salt Lake City.

1962 "The Mesoamerican pictorial manuscripts : research, past and present ", Akten des 34 Internationalen Amerikanistenkongresses, Wien, 1960, pp. 199-215, Vienna.

1962b «Activities of the archaeological survey, Los Angeles : 1961-1962. Report to president Clark Kerr and chancellor Franklin D. Murphy for the year ending June 30, 1962 », Archaeological Survey, Anmual Report, 1961-1962, pp. x-xvi, Department of anthropology and sociology, University of California, Los Angeles.

1962c «Ethnohistory: Mesoamerica» (introduction and annotated bibliography), Handbook of Latin American Studies, 24, pp. 56-66, Gainesville.

1962d «Interrelationships of New World cultures, project A : Central and South Pacific Coast, Mexico. Preliminary report, 1960 Season » [avec Jack Smith], Katumob, III (3), pp. 5-8, Oshkosh.

1962e "Notes and News : Middle America », American Antiquity, 27 (4), pp. 617-624, Salt Lake City.

$1962 \mathrm{f}$ «Review : Donald Brand et al., Coalcoman and Motines del Oro : An Ex-Distrito of Michoacan, Mexico », American Anthropologist, 64 (2), pp. 397-400, Menasha.

1962g «Review : Eduard Seler, Gesammelte Abhandlungen zur Amerikanischen Sprachund Altertumskunde » [reprint edition, 1960-1961, 5 vols], American Anthropologist, 64 (5), pp. 1097-1101, Menasha.

1963 "Pre-Hispanic Central Mexico : major sculpture » [submitted for publication in the Handbook of Middle American Indians], Los Angeles [mimeographed].

1963b "An Aztec stone image of fertility goddess », Baessler-Archiv, XI (1), pp. 9-30, Berlin.

1963c «The interrelationships of New World cultures. A coordinated research program of the Institute of Andean research, project A : Central Pacific Coast of Mexico (principal investigators: Clement Meighan and Henry B. Nicholson). Preliminary report : third field season, 1961-1962 », Katunob, IV (1), pp. 39-51, Oshkosh. 
1963d "The concept of history in pre-hispanic Mesoamerica 》 (résumé), VI Congrès international des sciences anthropologiques et ethnologiques, Paris, 30 juillet6 août 1960, II, Ethnologie (premier volume), Paris, [s. n.], p. 445.

1963e "Bandelier, Adolphe Francis Alphonse ", Encyclopedia Britannica, 3, p. 79, New York.

$1963 \mathrm{f}$ "Ethnohistory: Mesoamerica (introduction and annotated bibliography), Handbook of Latin American Studies, 25, pp. 50-51, Gainesville.

$1963 \mathrm{~g}$ "Activities of the archaeological survey, Los Angeles : 1962-1963. Report to president Clark Kerr and chancellor Franklin D. Murphy for the year ending June 30, 1963 », Archaeological Survey, Annual Report, 1962-1963, pp. v-xviii, University of California, Department of anthropology, Los Angeles.

1963h «Ixtapaluca Viejo Ballcourt (Mexico) » [avec David Grove], Katunob, IV (4), Oshkosh.

1964 "An Aztec stone image of a fertility goddess : addenda ", Baessler-Archiv, XIII, pp. 235-237, Berlin.

$1964 \mathrm{~b}$ «Pre-Hispanic Central Mexico : religion » [submitted for publication in the Handbook of Middle American Indians], Los Angeles [mimeographed].

$1964 \mathrm{c}$ "The ethnogeography of contact and early colonial Mesoamerica : reconstructive methods and problems (summary) ", XIV Congreso internacional de Americanistas, México, 1962, Actas y Memorias, vol. 2, Instituto Nacional de Antropología e Historia, Mexico, pp. 131-132.

1964d "Excavation of Ballcourt at Ixtapaluca, Valley of Mexico » [avec David Grove], Los Angeles [mimeographed].

1964e "The transition from Classic to Postclassic at Cerro Portezuelo, Valle of Mexico » [avec Frederick Hicks], XXXV Congreso Internacional de Americanistas, México, 1962, Actas y Memorias, vol. 1, Instituto Nacional de Antropología e Historia, Mexico, pp. 493-506.

1964 " Activities of archaeological survey, Los Angeles : 1963-1964; report to president Clark Kerr and chancellor Franklin D. Murphy for the year ending June 30, 1964 », Archaeological Survey, Annual Report, 1963-1964, pp. v-xviii, University of California, Department of anthropology, Los Angeles.

$1964 \mathrm{~g}$ "Review : Paul Westheim, The sculpture of Ancient Mexico. La escultura del México Antiguo », American Anthropologist, 66 (1), pp. 196-197, Menasha.

1964h "Review : Miguel León-Portilla, Aztec thought and culture », Hispanic American Historical Review, XLII (4), pp. 591-594, Durham, North Carolina.

$1964 \mathrm{i}$ «Review : Doris Heyden, Fernando Horcasitas, and Ignacio Bernal, The Aztecs : the history of the Indies of New Spain (Fray Diego Duran) ", American Anthropologist, 66 (6), pp. 1408-1411, Menasha.

1965 "Ethnohistory: Mesoamerica " (introduction and annotated bibliography), Handbook of Latin American Studies, 27, pp. 75-96, Gainesville.

1965 b "Review : Gunter Zimmermann, Die Relationen Chimalpahin's zur Geschichte Mexico's; Teil 1: Die Zeit bis zur Conquista 1521 », American Antiquity, 31 (1), pp. 120-122, Salt Lake City.

1965c «Review: Charles E. Dibble and Arthur J. O. Anderson, Florentine Codex: general history of the things of New Spain, Book 11-Earthly Things. Fray Bernardino de Sahagún », American Anthropologist, 67 (5), part 1, pp. 1325-1327, Menasha. 
1966 "The Mixteca-Puebla concept in Mesoamerican archaeology: a re-examination ", in John A. Graham (éd.), Ancient Mesoamerica : selected readings, Palo Alto, CA, pp. 258-263 [reprint of 1960 article].

1966b «The problem of the Provenience of members of the Codex Borgia Group : a summary ", in Antonio Pompa y Pompa (éd.), Summa Anthropologica en Homenaje a Roberto J. Weitlaner, Instituto Nacional de Antropología e Historia, Mexico, pp. 145-158.

1966c "The significance of the "Looped Cord" year symbol in Pre-Hispanic Mexico : an hypothesis ", Estudios de Cultura Náhuatl, VI, pp. 135-148, Mexico.

1966d "Another place-glyph with representations of Mushrooms », Tlalocan, V (2), pp. 109-111, Mexico.

1966e «Excavación de un juego de pelota en Ixtapaluca Viejo, Valle de México » [avec David Grove], Instituto Nacional de Antropología e Historia. Boletin, 22, pp. 1719, Mexico.

1966f "Review : Bodo Spranz, Gottergestalten in den mexikanischen Bilderhandschriften der Codex Borgia-Gruppe: Eine ikonographische Untersuchung ", American Anthropologist, 68 (3), pp. 798-801, Menasha.

$1966 \mathrm{~g}$ «Review : Gunter Zimmermann, Die Relationen Chimalpahin's zur Geschichte Mexico's : Teil 2 : Das Jahrhundert nach der Conquista (1522-1615) ", American Antiquity, 31 (6), pp. 886-887, Salt Lake City.

1966h "Review : Eduardo Noguera, La cerámica arqueológica de Mesoamerica », Anales de Antropología, III, pp. 287-291, Mexico.

1966i «Review: Eduard Seler, Comentarios al Códice Borgia », Tlalocan, V (2), pp. 125-132, Mexico.

1967 «A royal headband of the Tlaxcalteca », Revista Mexicana de Estudios Antropológicos, XXI, pp. 71-106, Mexico.

1967b « The efflorescence of Mesoamerican civilization : a resumé », in Betty Bell (éd.), Indian Mexico : past and present. Symposium papers, 1965, UCLA, Latin American Center, Latin American Studies 7, Los Angeles, pp. 46-71.

1967c "A fragment of an Aztec relief carving of the Earth Monster », Journal de la Societé des Américanistes, LVI (1), pp. 81-94, Paris.

1967d «Ethnohistory: Mesoamerica (introduction and annotated bibliography), Handbook of Latin American Studies, 29, pp. 156-199, Gainesville.

1967e "Ethnohistory: Mesoamerica », in Howard F. Cline (éd.), Latin American history : essays in its study and teaching, 1898-1965 [published for the conference on Latin American History], University of Texas Press, Austin, Texas, pp. 631-633 [reprint of 1960 introduction to Handbook of Latin American Studies annotated bibliography].

1967f «Review : Alfonso Caso, Interpretación del Códice Selden 3135 (A. 2) », American Antiquity, 32, pp. 257-258, Salt Lake City.

1967g "Review : Abraham Arias-Larreta, Pre-Columbian literaturas », Hispanic American Historical Review, XLVII, pp. 388-390, Durham, North Carolina.

1968 Two Aztec wood idols: iconographic and chronological analysis [avec Rainer Berger], Dumbarton Oaks, The Precolumbian Collection, Studies in PreColumbian Art and Archaeology 5, Washington, DC. 
1968b «Native tradition pictorials from the state of Puebla, Mexico : a preliminary classification an analysis " [duplicated].

1968c "Review : Alfonso Caso, Interpretación del Códice colombino », Anales de Antropología, V, pp. 280-287, Mexico.

1968d "Review: Cottie Burland, The Gods of Mexico ", American Anthropologist, 70 (4), pp. 821-822, Menasha.

1969 "West Mexican radiocarbon dates of archaeologic significance » [avec R. E. Taylor, Rainer Berger et Clement W. Meighan], in Jay D. Frierman (éd.), The Natalie Wood collection of Pre-Columbian ceramics from Chupicuaro, Guanajuato, Mexico, at UCLA, University of California, Occasional papers of the Museum and Laboratories of ethnic arts and technology 1, Los Angeles, pp. 17-30.

1970 «The Ceramic Mortuary Offerings of Prehistoric West Mexico : An Archaeological Perspective » [avec Clement W. Meighan], in Michael Kan, Clement W. Meighan et Henry B. Nicholson (éds), Sculpture of Ancient West Mexico. Nayarit, Jalisco, Colima: The Proctor Stafford Collection, Los Angeles County Museum of Art, July-August 30, 1970, Los Angeles, pp. 17-32.

$1970 \mathrm{~b}$ "Ethnohistory : Mesoamerica » (introduction and annotated bibliography), in Handbook of Latin American Studies, n 32, pp. 60-103, [s. n.], Gainesville.

1971 "The iconography of Classic Central Veracruz ceramic sculptures ", in Ancient Art of Veracruz. An exhibit sponsored by the Ethnic Arts Council of Los Angeles at the Los Angeles County Museum of Natural History, February 23-June 13, 1971, The Ethnic Arts Council of Los Angeles, Los Angeles, pp. 13-17.

1971b «The religious-ritual system of Late Pre-Hispanic Central Mexico », Verhanslungen des XXXVIII Internationalen Amerikanistenkongresses, StuttgartMunchen, 12. bis. 18. August 1968, Band III, pp. 223-238.

1971c "Major sculpture in Pre-Hispanic Central Mexico », in Robert Wauchope, Gordon Ekholm et Ignacio Bernal (éds), Handbook of Middle American Indians. Archaeology of Northern Mesoamerica, vol. 10, part 1, University of Texas Press, Austin, Texas, pp. 92-134.

1971d "Religion in Pre-Hispanic Central Mexico », in Robert Wauchope, Gordon Ekholm et Ignacio Bernal (éds), Handbook of Middle American Indians. Archaeology of Northern Mesoamerica, vol. 10, part 1, University of Texas Press, Austin, Texas, pp. 395-446.

1971e «Pre-Hispanic Central Mexican historiography», Investigaciones contemporáneas sobre historia de México. Memorias de la tercera reunión de historiadores Mexicanos y Norteamericanos, Oaxtepec, Morelos, 4-7 de Noviembre de 1969, Universidad Nacional Autónoma de México, El Colegio de México, The University of Texas at Austin, Mexico, pp. 38-81.

1972 «The problem of the historical identification of the Cerro Portezuelo/San Antonio archaeological site : an hipothesis ", Teotihuacan : XI Mesa Redonda, Sociedad Mexicana de Antropología, Mexico, pp. 157-200.

1972b "The cult of Xipe Totec in Mesoamerica », in Jaime Litvak King et Noemí Castillo Terejo (éds), Religión en Mesoamérica : XII Mesa Redonda, Sociedad Mexicana de Antropología, Mexico, pp. 213-218.

1972c "The iconography of Aztec period representations of the Earth Monster: Tlaltecuhtli (Sumario) », in Jaime Litvak King et Noemí Castillo Terejo (éds), 
Religión en Mesoamérica : XII Mesa Redonda, Sociedad Mexicana de Antropología, Mexico, pp. 225.

1972d «Review : Kart A. Nowotny (éd.) : Codex Cospi : Calendario Mexicano 4093, Biblioteca Universitaria Bologna, Códices Selecti, Phototypice Impressi, vol. XVIII, Graz, Austria, Akademische Druck-u. Verlagsanstalt », American Anthropologist, 74 (4), pp. 864-867, Washington, DC.

1973 "The Late Pre-Hispanic Central Mexican (Aztec) iconographic system ", The iconography of Middle American Sculpture, the Metropolitan Museum of Art, New York, pp. 72-97.

1973b "Phoneticism in the Late Pre-Hispanic Central Mexican writing system », in Elizabeth P. Benson (éd.), Mesoamerican writing systems : a conference at Dumbarton Oaks, October 30th and 31st, 1971, Dumbarton Oaks Research Library and Collections, Trustees for Harvard University, Washington, DC, pp. 1-46.

1973c «Sahagun's Primeros Memoriales, Tepeopulco, 1559-1561 », in Robert Wauchope, Howard F. Cline et John B. Glass (éds), Handbook of Middle American Indians. Guide to ethmohistorical sources, vol. 13, part 2, University of Texas Press, Austin, Texas, pp. 207-218.

1973d "Eduard George Seler, 1849-1922 », in Robert Wauchope, Howard F. Cline et John B. Glass (éds), Handbook of Middle American Indians. Guide to ethnohistorical sources, vol. 13, part 2, University of Texas Press, Austin, Texas, pp. 348-369.

1974 "The UCLA Department of anthropology program in West Mexican archaeology-ethnohistory, 1956-1970 » [with Clement W. Meighan], in Betty Bell (éd.), The archaeology of West Mexico, West Mexican Society for Advanced Study, Ajijic, Jalisco, Mexico, pp. 6-18.

1974b «Tepepolco, the locale of the first stage of Fr. Bernardino de Sahagún's great ethnographic project : historical and cultural notes "), in Normand Hammond (éd.), Mesoamerican archaeology : new approaches, Duckworth, Londres, Austin, Texas, pp. 145-154.

1974c "Some remarks on the provenience of Codex Borbonicus », Adeva Mitteilungen, 40, pp. 14-18, Akademische Druck-u. Verlagsanstalt, Graz, Austria.

1975 "Middle American ethnohistory : an overview ", in Robert Wauchope, Howard F. Cline, Charles Gibson et Henry B. Nicholson (éds), Handbook of Middle American Indians. Guide to ethnohistorical sources, vol. 15, part 4, University of Texas Press, Austin, Texas, pp. 487-505.

1975b "A Lowland Maya Long Count/Gregorian conversion computer program » [avec R. V. Sidrys et C. M. Krowne], American Antiquity, 40 (3), pp. 337-344, Washington, DC.

1975c «Review : Burr C. Brundage, A Rain of Darts : the Mexica Aztecs, University of Texas Press, Austin and London, 1972 », Hispanic American Historical Review, LV, pp. 772-774, Durham, North Carolina.

1976 «Los principales Dioses Mesoamericanos », Esplendor del México Antiguo, I, pp. 161-178 [2 édition, Mexico, reprint of 1959 article].

1976b Editeur, Origins of religious art iconography in Preclassic Mesoamerica [symposium volume of papers presented at the UCLA conference with this title, February 24-25, 1973], University of California, Latin American Center, UCLA Latin American Studies series 31, Los Angeles. 
1976c «Introduction » et « Preclassic Mesoamerican iconography from the perspective of the Post-Classic : problems in interpretational analysis », in Henry B. Nicholson (éd.), Origins of religious art iconography in Preclassic Mesoamerica [symposium volume of papers presented at the UCLA conference with this title, February 24-25, 1973], University of California, Latin American Center, UCLA Latin American Studies series 31, Los Angeles, pp. 3-6 et 159-175.

1977 «The Mixteca-Puebla concept in Mesoamerican archacology : a re-examination ", in Alana Cordy-Collins et Jean Stern (éds), Pre-Columbian art history : selected readings, Palo Alto, California, pp. 145-165 [reprint of 1960 article].

1977b "An Aztec stone image of fertility goddess », " An Aztec stone image of fertility goddess : addenda », in Alana Cordy-Collins et Jean Stern (éds), Pre-Columbian art history : selected readings, Palo Alto, California, pp. 145-165 [reprint of 1963 et 1964 articles].

1978 "Western Mesoamerican native historical and the chronology of the Postclassic ", in Clement W. Meighan et R. E. Taylor (éds), Chronologies in New World Archaeology, Academic Press, New York, pp. 285-329.

1978b "The Deity 9 Wind "Ehecatl-Quetzalcoatl" in the Mixteca Pictorials », Journal of Latin American Lore, 4 (1), pp. 61-92, Los Angeles.

1979 «Ehecatl Quetzalcoatl vs. Topiltzin Quetzalcoatl of Tollan : a problem in Mesoamerican history and religion", in Actes du XLII Congrès international des Americanistes (Congrès du Centenaire), Paris, 2-9 Septembre 1976, VI, Société des Américanistes, Paris, pp. 35-47.

1979b «Correlating Mesoamerican historical traditions with archaeological sequences : some methodological considerations ", in Actes du XLII Congrès international des Americanistes (Congrès du Centenaire), Paris, 2-9 Septembre 1976, IX-B, Société des Américanistes, Paris, pp. 187-198.

1979c «An Aztec stone monument dedicated to the Solar Cult : an iconographic analysis » (résumé), in Program and abstracts : XLIII international congress of Americanists, Vancouver, Canada, August 11-17, 1979, University of British Columbia, Simon Fraser University, Vancouver, p. 92.

1979d «Topiltzin Quetzalcoatl of Tollan : the primary sources considered » (résumé), in Program and abstracts: XLIII international congress of Americanists, Vancouver, Canada, August 11-17, 1979, University of British Columbia, Simon Fraser University, Vancouver, p. 92.

1980 "Aztec », World Book Encyclopedia, 1 (A), [s. n.], Chicago, pp. 971-976.

1980b "The Aztecs », in Arthur B. Cotterell (éd.), The Encyclopedia of Ancient Civilizations, Rainbird Publishing Group Limited, Londres/New York, pp. 142-148.

1981 "Forward ", in Patricia Rieff Anawalt, Indian Clothing before Cortès : Mesoamerican Costumes from the Codices, University of Oklahoma Press, Norman, Oklahoma, pp. xiii-xv.

$1981 \mathrm{~b}$ «The Mixteca-Puebla concept in Mesoamerican archaeology: a re-examination ", in John A. Graham (éd.), Ancient Mesoamerica : selected readings, Palo Alto, California, pp. 253-258 [second edition, reprint of 1960 article].

1982 «Revelation of the Great Temple », Natural History, 91 (7), July 1982, pp. 48-58, New York. 
1982b «Introduction : the importance of Late Post-Classic Central Mexico for Mesoamerican Studies ", in Elizabeth P. Benson et Elizabeth Hill Boone (éds), The art and iconography of Late Post-Classic Central Mexico : a conference at Dumbarton Oaks, October 22nd and 23rd, 1977, Dumbarton Oaks, Trustees for Harvard University, Washington, DC, pp. 1-6.

1982c «The Mixteca-Puebla concept revisited », in Elizabeth P. Benson et Elizabeth Hill Boone (éds), The art and iconography of Late Post-Classic Central Mexico : a conference at Dumbarton Oaks, October 22nd and 23rd, 1977, Dumbarton Oaks, Trustees for Harvard University, Washington, DC, pp. 227-254.

1983 "Mesoamerican ethnohistorical sources and their relevance to Pre-Hispanic settlement pattern studies ", in Evon Z. Vogt et Richard R. Leventhal (éds), Prehistoric settlement patterns : essays in Honor of Gordon R. Willey, University of New Mexico Press, Peabody Museum of Archaeology and Ethnology, Harvard University, Cambridge, Massachusetts, pp. 399-412.

1983 b "The iconography of Tepeyollotl, a Postclassic Western Mesoamerican Deity » (résumé), Latin American Indian Literatures Association Newsletter, 2 (1), pp. 9 10, Beaver Falls, Pennsylvania.

1983c Art of Aztec Mexico : treasures of Tenochtitlan. Catalogue of international exhibition of Aztec Art [avec Eloise Quiñones Keber], September 28, 1983-January 8, 1984, National Gallery of Art, Washington DC.

1984 «Review : David Carrasco, Quetzalcoatl and the irony of empire: myths and prophecies in the Aztec tradition, The University of Chicago Press, Chicago and London, 1982 », Man : Journal of the Royal Anthropological Institute, Series 2, 19 (4), pp. 674-675, Londres.

1984b "Problems in the interpretation of Aztec Art 》 (résumé), Latin American Indian Literatures Association Newsletter, 3 (1), p. 21, Beaver Falls, Pennsylvania.

1985 "The New Tenochtitlan Templo Mayor Coyolxauhqui-Chantico monument », Indiana (Gedenkschrift Gerdt Kutscher, Teil 2), 10, pp. 77-98, Berlin.

1985 b "Recollections of Gerdt Kutscher », Indiana (Gedenkschrift Gerdt Kutscher, Teil 2), 10, pp. 526-527, Berlin.

1985c «Polychrome on Aztec sculpture », in Elizabeth Hill Boone (éd.), Painted architecture and polychrome monumental sculpture in Mesoamerica : a symposium at Dumbarton Oaks, 10th to 11th October 1981, Dumbarton Oaks, Trustees for Harvard University, Washington, DC, pp. 145-171.

1985d "Grosse Ausstellung Aztekischer Kunst in Washington, DC » (traduit de l'anglais par Heidi King), Mitteilungen der Berliner Gesellschaft fur Anthropologie, Ethnologie und Urgeschichte, 6, pp. 21-32, Berlin.

1986 "Zur Entdeckungsgeschichte der aztekischen Kunst » (essentially derived from introduction in Nicholson and Quiñones Keber 1983), Glanz und Untergang des alten Mexiko : Die Azteken und ihre Vorlaufer, Roemer- und Pelizaeus-Museum, Hildesheim, and Verlag Phillipp von Zabern, Mainz, West Germany pp. 189-195.

1986b «Review article: J. Richard Andrews and Ross Hassing (editors and translators), "Treatise on the Heathen Superstitions that Today Live among the Indians Native to this New Spain, by Hernando Ruiz de Alarcón", "Aztec Sorcerers in Seventeenth Century Mexico : The Treatise on Superstitions by Hernando Ruiz de Alarcón" ", Ethmohistory, 33 (1), pp. 77-83, Durham, North Carolina. 
1987 «Symposium on the Aztec Templo Mayor : discussion », in Elizabeth Hill Boone (éd.), The Aztec Templo Mayor : A Symposium at Dumbarton Oaks, 8th and 9th October 1983, Dumbarton Oaks Research Library and Collection, Trustees for Harvard University, Washington, DC, pp. 463-484.

1987b "Mesoamerican religions: Postclassic culture ", in Mircea Eliade (éd.), The Encyclopedia of Religion, 9, Mac Millan Publishing Co., New York, pp. 419-428.

1987c "Iconography : Mesoamerican iconography », in Mircea Eliade (éd.), The Encyclopedia of Religion, 7, Mac Millan Publishing Co., New York, pp. 21-27.

1987d "The "Feathered Serpents" of Copan », in Gary W. Pahl (éd.), The Periphery' of the Southeastern Classic Maya Realm, UCLA, Latin American Studies Series, 61, Los Angeles, pp. 170-188.

1988 The Work of Bernardino de Sahagún : Pioneer Ethnographer of Sixteenth Century Aztec Mexico, avec J. Jorge Klor de Alva et Eloise Quiñones Keber, The University at Albany, Institute for Mesoamerican Studies, State University of New York, Studies on Culture and Society, 2, New York.

1988b " Introduction », in J. Jorge Klor de Alva, Henry B. Nicholson et Eloise Quiñones Keber (éds), The Work of Bernardino de Sahagún : Pioneer Ethnographer of Sixteenth Century Aztec Mexico, The University at Albany, Institute for Mesoamerican Studies, State University of New York, Studies on Culture and Society, 2, New York, pp. 1-11.

1988c "Recent Sahaguntine studies: a review », in J. Jorge Klor de Alva, Henry B. Nicholson et Eloise Quiñones Keber (éds), The Work of Bernardino de Sahagún : Pioneer Ethnographer of Sixteenth Century Aztec Mexico, The University at Albany, Institute for Mesoamerican Studies, State University of New York, Studies on Culture and Society, 2, New York, pp. 13-30.

1988d "The iconography of the Deity representations in Fray Bernardino de Sahagún's Primeros Memoriales: Huitzilopochtli and Chalchiuhtlicue ", in J. Jorge Klor de Alva, Henry B. Nicholson et Eloise Quiñones Keber (éds), The Work of Bernardino de Sahagún: Pioneer Ethmographer of Sixteenth Century Aztec Mexico, The University at Albany, Institute for Mesoamerican Studies, State University of New York, Studies on Culture and Society, 2, New York, pp. 229-253.

1988e "The Provenience of the Codex Borbonicus : an hypothesis ", in J. Kathryn Josserand et Karen Dakin (éds), Henry B. Nicholson, Doris Heyden, Karen Dakin et Nicholas A. Hopkins (coord.), Smoke and Mist : Mesoamerican Studies in Memory of Thelma Sullivan, British Archaeological Reports (BAR), International Series 402 (i), Part I, Oxford, England, pp. 77-97.

$1988 \mathrm{f}$ "Studies of Sahagún and other early sources : introduction », in J. Kathryn Josserand et Karen Dakin (éds), Henry B. Nicholson, Doris Heyden, Karen Dakin et Nicholas A. Hopkins (coord.), Smoke and Mist : Mesoamerican Studies in Memory of Thelma Sullivan, British Archaeological Reports (BAR), International Series 402 (i), Part I, Oxford, England, pp. 13-14.

1988g «Introduction : research concerning the Mesoamerican Ritual Ballgame », in Ted J. J. Leyenaar et Lee A. Parsons (éds), Ulama : the ballgame of the Mayas and Aztec. From human sacrifice to sport (text in English and Dutch), Spruyt Van Mantgem \& De Does bv, Leiden, The Netherlands, pp. 11-21. 
1988h "A Carved Teponaztli with the Representation of a Dancer in Fish Disguise ", in Elizabeth Reichel (éd.), Memorias del 45 Congreso Internacional de Americanistas, Universidad de los Andes, Bogotá, Colombia, Julio 1-7, 1985, vol. 2, Identidad y transformación de las Américas, pp. 320-333.

$1988 \mathrm{i}$ «Pictorial images of Aztlán : a comparative analysis 》 (résumé), Latin American Indian Literatures Associations Newsletter, 7 (1), p. 9, Ithaca, New York.

1989 «The ceramic mortuary offerings of Prehistoric West México : an archaeological perspective » [avec Clement W. Meighan], in Sculpture of Ancient West México, Nayarit, Jalisco, Colima : a catalogue of the Proctor Stafford collection at the Los Angeles County Museum of Art, Los Angeles County Museum of Art, University of New Mexico Press, Albuquerque, New Mexico, pp. 29-69.

1989b "The Cult of Xipe Totec in Pre-Hispanic West México », in Yólotl González (éd.), Homenaje a Isabel Kelly, Instituto Nacional de Antropología e Historia, Serie Arqueología, Mexico pp. 109-119.

1990 "Late Pre-Hispanic Central Mexican ("Aztec") sacred architecture : the pyramid temple ", in Bruno Illius et Mathias Laubscher (éds), Circumpacifica Festschrift fur Thomas S. Barthel, Verlag Peter Lang GmbH., Frankfurt am Main, pp. 303-324.

1991 "The Octli Cult in Late Pre-Hispanic Central México ", in David Carrasco (éd.), To change place: Aztec ceremonial landscapes, University Press of Colorado, Niwot, Colorado, pp. 158-187.

1991b «Ballcourt images in Central Mexican Native tradition pictorial manuscripts » [avec Eloise Quiñones Keber], in Gerard W. van Bussel, Paul L. F. van Dongen et Ted J. J. Leyenaar (éds), The Mesoamerican ballgame: papers presented at the international colloquium The Mesoamerican Ballgame 2000 BC-AD 2000, Leiden, June 30th-July 3rd, 1988, Rijksmuseum voor Volkenkunde, Leiden, pp. 119-134.

1992 "The History of the Codex Mendoza », in Francés Frei Berdan et Patricia Rieff Anawalt (éds), The Codex Mendoza (4 vols), University of California Press, Berkeley, vol. 1, pp. 1-11.

1992b "Aztecs and their neighbors », in Silvio A. Bedini (éd.), The Christopher Columbus Encyclopedia, Simon and Schuster, New York, vol. 1, pp. 364-368.

1992c "Motecuhzoma II ", in Silvio A. Bedini (éd.), The Christopher Columbus Encyclopedia, Simon and Schuster, New York, vol. 2, pp. 495-496.

1992d "A Cholulteca ceramic "Caricature" of a Totonac ", in Gabriela Uruñuela y Ladrón de Guevara (éd.), Selecciones del segundo simposio de Cholula. Notas Mesoamericanas, Universidad de las Américas, Puebla, nº 13, pp. 63-82.

1993 " The problem of the identification of the central image of the "Aztec Calendar Stone" ", in Alana Cordy-Collins et Douglas Sharon (éds), Current Topics in Aztec studies: essays in Honor of Dr. H. B. Nicholson, San Diego Museum Papers 30, San Diego, California, pp. 3-15.

1993b "Reminiscences : the San Diego Museum of Man and Balboa Park in the 1930s and 1940s », in Alana Cordy-Collins et Douglas Sharon (éds), Current Topics in Aztec studies: essays in Honor of Dr: H. B. Nicholson, San Diego Museum Papers 30, San Diego, California, pp. 111-118.

1993c "Foreward ", in Jane Stevenson Day (éd.), The fall of the Aztec Empire: the drawings of Keith Henderson, Denver Museum of Natural History and Roberts Rinehart Publisher, Niwot, Colorado. 
1993d «El Tocado Real de los Tlaxcaltecas », in Luis Reyes García (éd.), La escritura pictográfica en Tlaxcala : dos mil años de experiencia mesoamericana, Universidad Autónoma de Tlaxcala, Secretaría de Extensión Universitaria y Difusión Cultural, Centro de Investigaciones y Superiores en Antropología Social, colección « Historia de Tlaxcala »1, pp. 139-168 [traduction espagnole de « A royal headband of the Tlaxcalteca ", Revista Mexicana de Estudios Antropológicos, 1967, 1 (XXI), pp. 71-108].

1993e «Aztec style calendric inscriptions of possible historical significance : problems of the paired dates ", in Jacqueline de Durand-Forest et Marc Eisinger (éds), The symbolism in the plastic and pictorial representations of Ancient México: a symposium of the 46th International Congress of Americanists, Amsterdam, 1988, Holos Verlag, Bonner Amerikanistische Studien (Estudios Americanistas de Bonn) 21, Bonn, pp. 74-89.

1994 Mixteca-Puebla : discoveries and research in Mesoamerican art and archaeology, édité avec Eloise Quiñones Keber, Labyrinthos Press, Lancaster, California.

1994b «Introduction » [avec Eloise Quiñones Keber], in Nicholson Henry B. et Eloise Quiñones Keber (éds), Mixteca-Puebla : discoveries and research in Mesoamerican art and archaeology, Labyrinthos Press, Lancaster, California, pp. vii-xv.

1994c «The eagle claw/tied double maize ear motif : the Cholula polychrome ceramic tradition and some members of The Codex Borgia Group ", in Nicholson Henry B. et Eloise Quiñones Keber (éds), Mixteca-Puebla : discoveries and research in Mesoamerican art and archaeology, Labyrinthos Press, Lancaster, California, pp. 101-118.

1994d «The Mixteca-Puebla concept in Mesoamerican archaeology : a further examination » [avec Eloise Quiñones Keber], in E. Wyllys Andrews V et Elizabeth Oster Mozzillo (éds), Five Hundred Years after Columbus : proceedings of the 47th International Congress of Americanists, Tulane University, Middle American Research Institute, Publication 63, New Orleans, pp. 102-105.

1994e "Introduction : a tribute to Arthur J. O. Anderson and Charles E. Dibble, Huey Tlamatinime ", in Eloise Quiñones Keber (éd.), Susan Schroeder et Frederic Hicks (collab.), Chipping away on earth: studies in prehispanic and colonial México in Honor of Arthur J. O. Anderson and Charles E. Dibble, Labyrinthos Press, Lancaster, California, pp. xi-xv.

1995 "Three fragmentary Aztec monuments dedicated to the Solar cult : iconographic interpretations ", in Jacqueline de Durand-Forest et Georges Baudot (éds), préface de Pierre Chaunu, Mille ans de civilisation mésoamericaines. Des Mayas aux Aztèques. Mélanges en l'honneur de Jacques Soustelle, II. La quête du Cinquième Soleil, Éditions L'Harmattan, Paris, pp. 331-356.

1996 "Aztec calendar stone », in Barbara A. Tenenbaum (éd.), Encyclopedia of Latin American History and Culture, vol. I, Charles Scribner's Sons (Macmillan Library Reference USA), New York, pp. 254-255.

1996b "Aztecs ", in Barbara A. Tenenbaum (éd.), Encyclopedia of Latin American History and Culture, vol. I, Charles Scribner's Sons (Macmillan Library Reference USA), New York, pp. 255-257.

1996c "Quetzalcoatl », in Barbara A. Tenenbaum (éd.), Encyclopedia of Latin American History and Culture, vol. I, Charles Scribner's Sons (Macmillan Library Reference USA), New York, pp. 508-509. 
1996e "Aztec ", in Jane Turner (éd.), The dictionary of art, vol. 2, Macmillan Publishers Ltd, Londres/Grove's Dictionaries Inc., New York, pp. 905-908.

$1996 \mathrm{f}$ "Mesoamerica : religion and iconography ", in Jane Turner (éd.), The dictionary of art, vol. 21, Macmillan Publishers Ltd, Londres/Grove's Dictionaries Inc., New York, pp. 182-187.

1996g «Mesoamerica : Mixtec », in Jane Turner (éd.), The dictionary of art, vol. 21, Macmillan Publishers Ltd, Londres/Grove's Dictionaries Inc., New York, pp. 736-739.

1996h «Mesoamerica : Mixteca-Puebla », in Jane Turner (éd.), The dictionary of art, vol. 21, Macmillan Publishers Ltd, Londres/Grove's Dictionaries Inc., New York, pp. 739-741.

1996i «The iconography of the Solar Deity, Tonatiuh, in the Late Prehispanic Central Mexican Pictorials » (résumé), III Simposio internacional de códices y documentos sobre México. Resúmenes, Instituto Nacional de Antropología e Historia, Mexico/Dirección de Estudios Históricos, Puebla, pp. 15-16.

1997 «Preface », pp. xi-xiii ; « Introduction », pp. 3-14; « References cited », pp. 299314 ; and majority of the Notes, in H. B. Nicholson, Arthur J. O. Anderson, Charles E. Dibble, Eloise Quiñones Keber et Wayne Ruwet (éds), Primeros Memoriales of Fray Bernardino de Sahagún: Paleography of Náhuatl Text and English Translation by Thelma D. Sullivan. Completed and revised, with additions, the University of Oklahoma Press, Norman, Oklahoma/Patrimonio Nacional and the Real Academia de la Historia, The Civilization of the American Indian Series 200, Madrid, p. 2.

1997b "The First Natives of Mesoamerica in Europe », in Leonardo Manrique C. et Noemí Castillo T. (éds), Homenaje al doctor Ignacio Bernal, Instituto Nacional de Antropología e Historia, Serie Historia, Colección Científica 333, Mexico, pp. 263-276.

1998 «Entrevista. Henry B. Nicholson : Presencia en la arqueología y la etnohistoria de Mesoamerica » [avec Bertina Olmedo Vera], Arqueología Mexicana, 6 (31), pp. 60-65, Mexico.

1998b "The native tradition pictorials in the Aubin-Goupil collection of Mesoamerican ethnohistorical documents in the Bibliothèque nationale de France : major reproductions and studies ", Journal de la Société des Américanistes, 84 (2), pp. $35-50$.

1999 "The Octli cult in Late Pre-Hispanic Central México ", in David Carrasco (éd.), To change place: Aztec ceremonial landscapes, University of Colorado Press, Niwot, Colorado, pp. 158-187 [second edition, paperback, with new introduction by William Fash].

2000 "The iconography of the feathered serpent in Late Postclassic Central México ", in David Carrasco, Lindsay Jones et Scott Sessions (éds), Mesoamerica's classic heritage : from Teotihuacan to the Aztecs, University Press of Colorado, Mesoamerican Worlds, From the Olmecs to the Danzantes, Boulder, pp. 145-164.

2000b «Hugh Thomas' conquest : observations on the coverage of the indigenous cultures ", in Eloise Quiñones Keber (éd.), In Chalchihuitl in Quetzalli : precious Greenstone, precious Quetzal feather. Mesoamerican studies in Honor of Doris Heyden, Labyrinthos, Lancaster, California, pp. 129-136. 
2000c «The Iconography of the Solar Deity Tonatiuh in the Late Prehispanic Central Mexican Pictorials ", in Constanza Vega Sosa (éd.), Códices y documentos sobre México. Tercer Simposio Internacional, Instituto Nacional de Antropología e Historia, Mexico, pp. 61-81.

2001 Topiltzin Quetzalcoatl: The once and future Lord of the Toltecs, University Press of Colorado, Mesoamerican Worlds, From the Olmecs to the Danzantes, Boulder.

$200 \mathrm{Ib}$ The "Return of Quetzalcoatl": did it play a role in the conquest of México?, Labyrinthos, Lancaster, California.

2001c "Cerro Portezuelo (México, México) », in Susan Toby Evans et David L. Webster (éds), Archaeology of Ancient México and Central America : an encyclopedia, Garland Publishing, Inc., New York/Londres, p. 114.

2001d Senior consulting editor, David Carrasco (éd.), The Oxford encyclopedia of Mesoamerican cultures : the civilizations of México and Central America, 3 vols, Oxford University Press, New York.

2001e "Borgia Group of pictorial manuscripts », in David Carrasco (éd.), The Oxford encyclopedia of Mesoamerican cultures : the civilizations of México and Central America, 3 vols, Oxford University Press, New York, vol. 1, pp. 98-101.

$2001 \mathrm{f} \mathrm{"Feathered} \mathrm{Serpent} \mathrm{",} \mathrm{in} \mathrm{David} \mathrm{Carrasco} \mathrm{(éd.),} \mathrm{The} \mathrm{Oxford} \mathrm{encyclopedia} \mathrm{of}$ Mesoamerican cultures : the civilizations of México and Central America, 3 vols, Oxford University Press, New York, vol. 1, pp. 396-400.

2001g "Mixteca-Puebla Style ", in David Carrasco (éd.), The Oxford encyclopedia of Mesoamerican cultures: the civilizations of México and Central America, 3 vols, Oxford University Press, New York, vol. 2, pp. 329-330.

$2001 \mathrm{~h}$ «Sahagún, Bernardino de ", in David Carrasco (éd.), The Oxford encyclopedia of Mesoamerican cultures : the civilizations of México and Central America, 3 vols, Oxford University Press, New York, vol. 3, pp. 105-113.

$2001 \mathrm{i}$ "Seler, Eduard ", in David Carrasco (éd.), The Oxford encyclopedia of Mesoamerican cultures: the civilizations of México and Central America, 3 vols, Oxford University Press, New York, vol. 3, pp. 134-137.

2001j "Topiltzin Quetzalcoatl », in David Carrasco (éd.), The Oxford encyclopedia of Mesoamerican cultures : the civilizations of México and Central America, 3 vols, Oxford University Press, New York, vol. 3, pp. 246-247.

2001k "The New Tenochtitlan Templo Mayor Coyolxauhqui-Chantico Monument ", in Carmen Aguilera (éd.), Coyolxauhqui : the Mexica milky way with a critical description of the Monument by H. B. Nicholson, Labyrinthos, Lancaster, California, pp. 105-125 [reprint of 1985 article, with added index].

2002 " The iconography of the feathered serpent in Late Postclassic Central México ", in David Carrasco, Lindsay Jones et Scott Sessions (éds), Mesoamerica's classic heritage : from Teotihuacan to the Aztecs, University Press of Colorado, Mesoamerican Worlds, From the Olmecs to the Danzantes, Boulder, pp. 145-164 [First paperback edition, University Press of Colorado, Boulder, Republication of article originally published in 2000 hardback edition, with Fig. 4.18. now correctly oriented].

2002b «Fray Bernardino de Sahagún : a spanish missionary in New Spain, 15291590 », in Eloise Quiñones Keber (éd.), Representing Aztec ritual : performance, 
text, and image in the work of Sahagún, University of Colorado Press, Mesoamerican Worlds, From the Olmecs to the Danzantes, Boulder, pp. 21-39.

2002c "Representing the Veintena Ceremonies in the Primeros Memoriales ", in Eloise Quiñones Keber (éd.), Representing Aztec ritual : performance, text, and image in the work of Sahagin, University of Colorado Press, Mesoamerican Worlds, From the Olmecs to the Danzantes, Boulder, pp. 63-106.

2002d "Reply to Michel Graulich's review of HBN's Topiltzin Quetzalcoatl : the once and future Lord of the Toltecs ", The Nahua Newsletter, 33, February, 2002, pp. 18-21.

2002e «Reply to Graulich Reply to HBN Reply to Graulich Review of HBN's Topiltzin Quetzalcoatl : the once and future Lord of the Toltecs », The Nahua Newsletter, 34, November, 2002, pp. 13-14.

2003 «Sahagún's itemization of the structures of the Templo Mayor Precinct of México Tenochtitlan: "legend" of a Lost Diagram?», in John Frederick Schwaller (éd.), Sahagín at 500 : essays on the Quincentenary of the Birth of Fr: Bernardino de Sahagún, Publications of the Academy of American Franciscan History, Franciscan Publications in Náhuatl Series vol. 3, Academy of American Franciscan History, Berkeley, California pp. 255-263.

2003 b "The Annual "Royal Ceremony" on Mt. Tlaloc : mountain fertility ritualism in the Late Pre-Hispanic Basin of México ", in Douglas Sharon (éd.), Mesas and cosmologies in Mesoamerica, San Diego Museum Papers 43, San Diego, California, pp. 33-49.

2004 "The headless ex-guardian of the eagle gate of the great temple precinct of México Tenochtitlan ? ", in Patrick Lesbre et Marie-José Vabre (éds), préface de Georges Baudot et Miguel León-Portilla, Le Mexique préhispanique et colonial : Hommage à Jacqueline de Durand-Forest, L'Harmattan, Paris, pp. 32-47.

2005 "A tale of two ballcourts : laguna de Moctezuma, Sierra de Tamaulipas (Tm r 304), and Ixtapaluca Viejo (Acozac), Basin of México ", in Brian D. Dillon et Matthew A. Boxt (éds), Archaeology without limits : papers in Honor of Clement W. Meighan, Labyrinthos, Lancaster, California, pp. 309-324.

2005b «Some personal reminiscences of Clement W. Meighan », In Archaeology without Limits : Papers in Honor of Clement W. Meighan, in Brian D. Dillon et Matthew A. Boxt (éds), Archaeology without limits : papers in Honor of Clement IV. Meighan, Labyrinthos, Lancaster, California, pp. 13-14.

2005c "Foreword ", in Leonardo López Lujan (éd.), The offerings of the Templo Mayor of Tenochtitlan [revised edition. Translated by Bernard R. Ortiz and Thelma Ortiz de Montellano], University of New México Press, Albuquerque, pp. xvii-xix.

2005d "Ce Acatl Nacxitl Topiltzin Quetzalcoatl of Tollan = 4 Jaguar of "Cattail Frieze" and military Ally of 8 Deer "Jaguar Claw" ? ", in Elizabeth H. Boone (éd.), Painted books and indigenous knowledge in Mesoamerica : manuscript studies in Honor of Mary Elizabeth Smith, Middle American Research Institute, Tulane University, publication 69, New Orleans, pp. 143-160.

2006 "The Stones of the Death Monsters », in Leonardo López Luján, David Carrasco et Lourdes Cué (éds), Arqueología e historia del Centro de México. Homenaje a Eduardo Matos Moctezuma, Instituto Nacional de Antropología e Historia, Mexico, pp. 369-388. 